\begin{tabular}{ccc}
\hline & International Journal of Current Research in \\
Biosciences and Plant Biology & Volume 5 • Number 10 (October-2018) ・ ISSN: 2349-8080 (Online) \\
\hline EXCELLENT \\
PUBLISHERS
\end{tabular}

Review Article

doi: $\underline{\text { https://doi.org/10.20546/ijcrbp.2018.510.003 }}$

\title{
Review on the Use of Black Pepper (Piper spp.) and Red Pepper (Capsicum spp.) as Grain Protectants
}

\section{Esther Pegalepo ${ }^{1 *}$, Aimé H. Bokonon-Ganta1, Joseph Dossou², Moussa Sie ${ }^{3}$ and Angèles Ndogho Pegalepo ${ }^{4}$}

${ }^{1}$ Laboratory of Agricultural Entomology (LEAg), Faculty of Agronomic Sciences (FSA), University of Abomey-Calavi (UAC), University Campus Abomey-Calavi,

03-B.P. 2819 Jéricho, Cotonou - Bénin

${ }^{2}$ Laboratory of Bio-Engineering of Food Processes (LABIOPA), Faculty of Agricultural Sciences (FSA),

University of Abomey-Calavi (UAC), University Campus of Abomey-Calavi,

03-B.P. 2819 Jéricho, Cotonou - Bénin

3Institute of Environment and Agricultural Research (INERA) of Burkina-Faso, 01 BP 910 Bobo-Dioulasso, Burkina Faso

${ }^{4}$ Laboratory of Phytopathology, Department of Plant Biology, University of Yaoundé I,

P.O. Box 812 Yaounde-Cameroon

*Corresponding author.

\section{Article Info \\ Date of Acceptance: \\ 21 September 2018 \\ Date of Publication: \\ 06 October 2018}

\section{Keywords}

Black pepper

Grain protectant

Red pepper

\section{Introduction}

Food is usually attacked by insects during their storage. Loss of food products is considerable in the humid tropics because of climate favorable to the development of pests (Foua-Bi, 1992). According to Togola (2010), losses from rice weevil are not important before tree months of storage of paddy rice, but these losses increase later and vary from $18-30 \%$ between 3-6 months. Mele (2007) reported 
that these losses can reach $100 \%$ between 6 and 12 months of storage if the infestation of the insects is too high. Primary insects stored are an internal feeder, and it is difficult to control with insecticides. Many studies have been made for controlling pests of grains. Several synthetic insecticides such as grains protectors and chemical fumigants are used by farmers on food grains for control of storage pests. These synthetic insecticides have not been sustainable because of their high costs and unavailability in local markets. Their negative effects arise from their residues on grains that affect consumers, wildlife, the environment and the development of genetically resistance pest (Wolfson et al., 1991). A survey made by Guèye et al. (2008) in Senegal highlighted the use of rodenticides, fungicides, herbicides or unidentified liquids on maize to be oriented for human consumption. In addition, the study found a total ignorance of the active ingredients and doses to be used. Guèye et al. (2011) reported after another survey that the color of the container seems to be the main retained criterion in the choice of the pesticide by the users. During application, farmers usually overuse the chemical because they just want to protect their stock against insect pests. In 2003, PAN Africa reported that yearly around 750,000 people contract chronic disease such as cancers, because of their exposure to pesticides. According to Harris (1999), the WHO in 1990 revised their estimates to 25 million cases of acute occupational pesticide poisoning in developing countries each year. According to the same author, 60 pesticide active ingredients have been classified by recognized authorities as being carcinogenic to some degree. 118 pesticides have been identified as disrupting hormonal balance.

As alternative solution of grain storage protection, many studies of the use of plant insecticides materials have been successful against insect pests. Because of their biodegradable effects, these plants do not have negative impact on the environment, as long as due care is taken. There is no need of sophisticated equipments for the application of these plant insecticides nor is there known repellents effect. Again, they are not expensive.
The successful use of these plant materials against insect pests as grain protectants is signaled by farmers and researchers all over the world; this included spices and powders of plant parts (Akinneye et al., 2006). Among the botanical products, spices are characterized by their flavor and odor due to the presence of aromatic oils. These volatile compounds can influence insect behavior. The protection of grain against insects stored generally involves mixing grains with plantbased compounds (Tapondjou et al., 2002). Spices are defined as dried seed, fruit, root, bark or vegetative substances used in insignificant quantities as a food additive for their flavor. Those spices are cheaper, affordable, easily available in the developing countries, safer and do not cause injuries to the users (Aslam et al., 2002; Mahdian and Rahman, 2008).

This review aims for the use of black pepper (Piper spp.) and red pepper (Capsicum spp.) as grain protectants, in grain storage to control insect pests with their toxicity and repellent effects, antifeeding effects and the inhibition of the reproduction.

\section{Biopesticidal activities of Piper spp. and Capsicum spp.}

According to Rajapakse (2006) and Emeasor et al. (2005), the modes of action of powders, plants, oils and extract vary, and the effects on stored grain insects are either repellent, inhibition of reproduction or toxic. It is never mechanical.

\section{Repellent effects of Piper spp. and Capsicum spp.}

The significant insect repellent effect of 85 Piper guineenses Schum and Thonn, due to the phytochemicals that it contains was mentioned by de Paula et al. (2000). Salvador et al. (2007) found that powders of $P$. nigrum had a repellent effect on Sitophilus zeamais. This result confirmed the finding of Ishii et al. (2010) who reported that Piperine, a principal active compound of black pepper, may play a role in the repellent activity against $S$. zeamais even at lower concentration. 
Shayesteh and Ashouri (2010) studied the repellency effect of the powder of black pepper (Piper nigrum) and chili pepper (Capsicum annuum) among four powder spices. The spices were at $2.5 \%(\mathrm{w} / \mathrm{w})$ on $200 \mathrm{~g}$ of wheat against three stored-product insects, the lesser grain borer, Rhyzopertha dominica, the granary weevil, Sitophilus granarius and the red flour beetle, Tribolium castaneum. The authors demonstrated that the repellency of these powder spices increased with the increase in dosage as well as the increase in the period of exposure to the plant powders. Repellent effect was more efficient on adults of $S$. granarius, followed by $T$. castaneum and $R$. dominica, after 1,6 and $24 \mathrm{~h}$, respectively (Figs. 1 and 2).

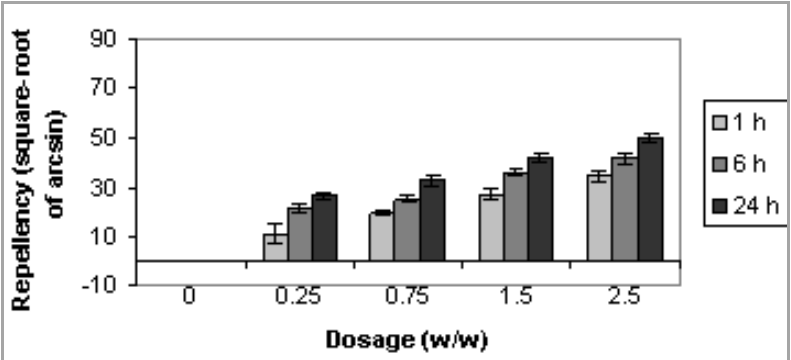

Fig. 1: Mean repellency of black pepper powder to Rhyzopertha dominica adults: Extract from Shayesteh and Ashouri (2010).

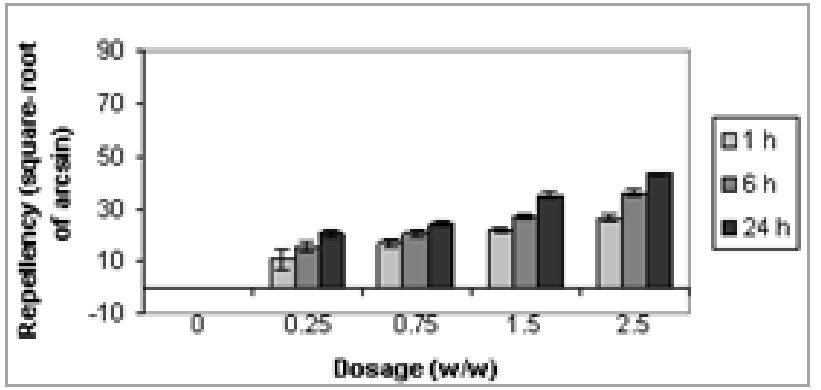

Fig. 2: Mean repellency of red pepper powder to Rhyzopertha dominica adult: Extract from Shayesteh and Ashouri (2010).

Udo (2005), after the evaluation of five local spices for their ability to protect stored maize against infestation of Sitophilus zeamais revealed that powder of $P$. guineenses had highly repellent effect of $80 \%$ on the maize weevils at the concentration of $1 \%$ and $5 \%(\mathrm{w} / \mathrm{w})$. Parmar et al. (1997), reported the pronounced effect of repellent and insecticidal effects of pepper fruit and black pepper seeds on the population of Callosbruchus maculatus. Sighamony et al. (1984), found that black pepper (P. nigrum) repelled $C$. chinensis more than the standard repellent dimethyl phthalate.

Previous research showed that some plant powders, oils and extracts mixed with grain have strong effects on stored grain insects such as toxicity, insect oviposition, egg hatchability, postembryonic development, and progeny production and the inhibition of reproduction (Emeasor et al., 2005; Nadra, 2006).

\section{Toxicity effect of Piper spp. and Capsicum spp. on the insect pests' inhibition of the reproduction and development of insects}

\section{Toxicity effect}

The effectiveness of these botanical insecticides could be due to the nature of their active compounds. Piperine which is a principal active compound of black pepper was demonstrated to have insecticidal effect. Huang and Ho (1998) and Lale (1995) gave more details on the toxicity of black pepper by saying that in addition to the Piperine, $P$. guineenses contains the Chavicine and the alkaloids that are pungent active compounds. For Rehm and Espigs (1991) the pungency of pepper fruit is caused by capsaicin and its level varies according to the cultivars.

Many spices that had been tried and found to be effective for controlling insect pests included powders from red peppers (Capsicum spp.) and black pepper (Piper spp.) (Emeasor et al., 2005; Nadra, 2006). The essential oils of some spices are reported to exhibit insecticidal activities (Owolabi et al., 2009). Credland (1992) reported that plant powders that caused ovicidal effect on bruchid, for example, blocked the respiration tract and prevented the normal exchange of gas between the external environment and the chorion thus causing asphysia of the insect. Ivbijaro and Agbaje (1986), and Olaifa et al. (1987) reported that black pepper (P. guineenses) possesses a high potential effect for use in insect pest control. 
Nadra (2004) noticed that $C$. frutescens caused high and significant mortality (85\%) of Trogoderma granarium adults at all concentrations $(1,2,4$ and $6 \%$ ), within 7 days. The study made by Echezona (2006) on four pepper cultivars 'Sombo', 'Nsukka Yellow', 'Tatashi' and 'Tanjarawa' in Nigeria against adult of Callosobruchus maculatus (F.) revealed that those peppers increased the mortality of adult of this insect than that one of the check; and attributed their efficacy to the pungency of the fruits.

Oparaeke and Bunmi (2006) found that more than $90 \%$ of mortality was recorded at three concentrations $(2.5,5.0$ and $7.5 \%$ per $150 \mathrm{~g})$ of seeds of $P$. guineenses powder on Callosobruchus subinnotatus due to the toxicity of the spices after $48 \mathrm{~h}$ of exposure of the C. subinnotatus. Owoade (2008) conducted an experiment to expose larvae of Dermestes maculatus to three concentrations (15, 20 and $25 \mathrm{~g} \cdot \mathrm{kg}^{-1}$ ) of $P$. guineenses and a mortality of $100 \%$ was reported in all the three concentrations by the end of 72 hours. However, Devi and Devi (2013) reported the effectiveness of $1 \%$ of black pepper powder against Sitophilus oryzae on $15 \mathrm{~g}$ of wheat after 21 days of exposure (see Table 1).

Table 1. Insecticidal activity of black pepper and red chilli against $S$. oryzae.

\begin{tabular}{lll}
\hline \multirow{2}{*}{ Spices } & Mortality (\%) \\
\cline { 2 - 3 } & $\mathbf{1 \%}$ & $\mathbf{5 \%}$ \\
\hline Black pepper & $100.0 \pm 0.00$ & $100.0 \pm 0.00$ \\
Red chilli & $4.9 \pm 2.95$ & $16.6 \pm 1.79$ \\
\hline
\end{tabular}

Extract from Kalpana and Sumithra (2013).

The insecticidal effect of black pepper ( $P$. nigrum), red pepper ( $C$. frutescens) and other spices was studied by Mahdian and Rahman (2008) against the pulse beetle, C. maculatus (F.) on stored black gram (Phaseolus bengalensis L.). The effectiveness of all the spices used was observed as protectants of black gram seeds but black pepper was the most effective.

\section{Antioviposition effect and inhibition of adult emergence}

The oviposition deterrence of chili pepper fruits powder against bruchid was found by Lale (1994).
Oparaeke and Bunmi, (2006) reported that the concentration of Piper guineenses powder of 2.5; 5.0 and $7.5 \%$ per 150 seeds significantly reduced oviposition by 85.44 to $90 \%$ while adult emergence and seed damage were reduced by $100 \%$ each. These concentrations used by Oparake and Bunni are very high. The results of Devi and Devi (2013) showed that with less amount of black pepper powder we can still have the same results (see Table 2 below).

Table 2. Effect of spice powders on F1 population against Sitophilus oryzae.

\begin{tabular}{lllll}
\hline \multirow{2}{*}{ Spices } & \multicolumn{3}{l}{ F1 Progeny } & \\
\cline { 2 - 5 } & $\mathbf{1 \%}$ & & $\mathbf{5 \%}$ & \\
\cline { 2 - 5 } & F1 no. & Inhibition \% & F1 no. & Inhibition \% \\
\hline Pepper & $0.0 \pm$ & 100.0 & $0.0 \pm$ & 100.0 \\
& 00.00 & & 00.00 & \\
Red chilli & $16.6 \pm$ & 56.4 & $49.0 \pm$ & 78.1 \\
& 1.79 & & 06.10 & \\
\hline \multirow{2}{*}{ Extract from Kalpana and Sumithra (2013). } &
\end{tabular}

Extract from Kalpana and Sumithra (2013).

With only $1 \%$ on $15 \mathrm{~g}$ of wheat, black pepper affected $100 \%$ on inhibition of progeny Upadhyay and Jaiswal (2007). Black pepper also significantly inhibits the development of larvae into pupae and pupae into adult. The suppression of the emergence of F1 progeny of $S$. zeamais in stored maize was demonstrated by the used of $P$. guineenses seeds powder at 5 and $10 \%(\mathrm{w} / \mathrm{w})$ concentration compared to $1 \%$ and the no protectant controls in laboratory conditions for 12 weeks (Donald et al., 2008). Chaubey (2008) and Miah et al. (1993) revealed that black pepper was effective in reducing adult's emergence.

\section{Antifeedant effect of Piper spp.}

Antifeeding activity and oviposition deterrence caused by the spices powders against insect stored could be the basis for reducing the emergence of progeny (Tapondjou et al., 2005; Akob and Ewete, 2007). Ntonifor et al. (2010), after the ingestion of the water and ethanol extracts of $P$. guineenses (at $\geq 100 \mathrm{ppm}$ ) against a third instar larva of Plutella xylostella in a 24 hours bioassay reported an antifeedant activity of the larvae and $100 \%$ mortality within two to three days after 
infestation. According to $\mathrm{Li}$ et al. (2014), the feeding-deterrent potential of Piper species could be general characteristic at genus level.

\section{Antioxidant and Capsicum spp.}

The antioxidant properties of Capsicum species have been well documented (Oboh and Rocha, 2006). Omodamiro and Ekeleme (2013) studied the antioxidant activity of $P$. guineenses. The result showed that the leaves of this plant exhibited free radical scavenging effects. This could be attributed to the presence of phenolic compounds in the plant which is a major group of compounds that act as primary antioxidants or free radical scavengers. In another study, the seed extracts of $P$. guineenses was found to rapidly scavenge nitric oxide in vitro at different intervals (Ngane et al., 2003).

\section{Conclusion}

Farmers in developing countries can rely on botanical insecticides, especially on edible one like spices to store their grain against insects. Capsicum spp. and Piper spp. are cheaper and easy to afford in the market. Regardless of their antifeeding and toxicity effects, the inhibition of the reproduction of the insect in store grain, these spices can be recommended to replace chemical insecticides without any cause of intoxication of human being and pollution of the environment.

\section{Conflict of interest statement}

Authors declare that they have no conflict of interest.

\section{References}

Akinneye, J.O., Adedire, C.O., Arannilewa, S.T., 2006. Potential of Cleisthopholis patens Elliot as a maize protectant against the stored product moth, Plodia interpunctella (Hubner) (Lepidoptera; Pyralidae). Afr. J. Biotechnol. 5(25), 2510-2515.

Akob, C.A., Ewete F.K., 2007. The efficacy of ashes of four locally used plant materials against Sitophilus zeamais (Coleoptera: Curculionidae) in Cameroon. Int. J. Trop. Insect Sci. 27(1), 21-26.

Aslam, M., Ali Khan, K.H., Bajwa, M.Z.H., 2002. Potency of some spices against Callosobruchus chinensis L. Online J. Biol. Sci. 2(7), 449-452.

Chaubey, M.K., 2008. Fumigant toxicity of essential oils from some common spices against pulse beetle, Callosobruchus chinensis (Coleoptera: Bruchidae). J. Oleo Sci. 57(3), 171-179.

Credland, P.F., 1992. The structure of bruchid eggs may explain the ovicidal effects of oils. J. Stored Prod. Res. 28, 1-9.

de Paula, V. F., Barbosa, L. C. D., Demuner, A. J., Pilo-Veloso D., Picanco, M. C., 2000. Synthesis and insecticidal activity of new amide derivatives of piperine. Pest Manag. Sci. 56, 168-174.

Devi, K. C., Devi, S. S., 2011. Insecticidal and oviposition deterrent properties of some spices against coleopteran beetle, Sitophilus oryzae. J Food Sci. Technol. 50(3), 600-604.

Donald, A. U., Gabriel, A. A., Emmanuel, I. O. 2008. Toxicity and oviposition deterrence of Piper guineense (Piperaceae) and Monodora myristica (Annonaceae) against Sitophilus zeamais (Motsch.) on stored maize. J. Entomol. 5, 295-299.

Echezona, B. C., 2006. Selection of pepper cultivars (Capsicum spp.) for the control of bruchids Callosobruchus maculatus (F.) on stored cowpea (Vigna unguiculata (L.) Walp.) seeds. Afr. J. Biotechnol. 5(8), 624-628.

Emeasor, K. C., Ogbuji, R. O., Emosairue, S. O., 2005. Insecticidal activity of some seed powders against Callosobruchus maculatus (F.) (Coleoptera: Bruchidae) on stored cowpea. J. Pl. Dis. Protect. 112(1), 80-87.

Foua-Bi, K., 1992. Préambule. In: La Post-récolte en Afrique (Eds. : Foua-Bi, K., Philogène, B.). Actes du Séminaire International de la Postrécolte en Afrique, Abidjan, Côte-d'Ivoire 29 Jan.-1er fév. 1990. Aupelf, Montmagny. pp.152-154.

Guèye, M.T., Badiane, M., Ndiaye, A.B., Mbaye, I., Diouf, M., Ndiaye, S., 2008. La protection 
des stocks de maïs au Sénégal: enquêtes sur les pratiques d'utilisation des pesticides et plantes à effet insecticide en milieu paysan. ITA Echos, $\mathrm{N}^{\circ} 3,12 \mathrm{p}$.

Guèye, M.T., Seck, D., Wathelet, J.P., Lognay, G., 2011. Lutte contre les ravageurs des stocks de céréales et de légumineuses au Sénégal et en Afrique occidentale. Biotechnol. Agron. Soc. Environ. 15(1), 187-198.

Harris, J., 1999. Pesticides in Perspective. http://www.nufarm.com/Assets/1138/1/Pesticid esinPerspective.pdf

Huang, Y., Ho, H.S., 1998. Toxicity and antifeedant activities of cinnamaldehyde against the grain storage insects, Tribolium castaneum (Herbst) and Sitophilus zeamais Motsch. J. Stored Prod. Res. 34, 11-17.

Ishii, T., Matsuzawa, H., Vairappan, C. S., 2010. Repellent activity of common spices against the rice weevil, Sitophilus zeamais Motsch (Coleoptera, Curculionidae). J. Trop. Biol. Conserv. 7, 75-80.

Ivbijaro, M.F., Agbaje, M., 1986. Insecticidal activities of Piper guineense Schum and Thonn., and Capsicum species on the cowpea Bruchid Callosobruchus maculatus F. Insect Sci. Appln. 7(4), 52-524.

Kalpana, C., Devi, Sumithra Devi, S., 2013. Insecticidal and oviposition deterrent properties of some spices against coleopteran beetle, Sitophilus oryzae. J. Food Sci. Technol. 50(3), 600-604.

Lale, N., 1994. Laboratory assessment of the effectiveness and persistence of powders of four spices on cowpea bruchid ad maize weevil in airtight facilities. Samaru J. Agric. Res. 11, 7984.

Lale, N., 1995. An overview of the use of plant products in the management of stored product Coleopterea in the tropics. Post Harvest News Infor. 6, 69-75.

Li, W. Z., Hu, J. J., Yang, J., Yuan, G. H., Guo, X. R., Luo, M. H., 2014. Feeding deterrence of common spices against Helicoverpa armigera larvae. Adv. Biosci. Biotechnol. 5, 1025-1031.

Mahdian, Sh. H. A., Rahman, M. Kh., 2008. Insecticidal effect of some spices on
Callosobruchus maculatus (Fabricius) in black gram seeds. Rajshahi Univ. Zool. Soc. 27, 4750.

Mele, M. O. G., 2007. Inventaire des insectes des stocks de riz au Bénin : Détermination des pertes occassionnées. Rapport de de fin de formation pour l'obtention de la licence professionnelle, Ecole Polytechnique d'Abomey-Calavi (EPAC) de l'Université d'Abomey-Calavi (UAC), Abomey-Calavi, Bénin, 73p.

Miah, M., Islam, B.N., Dewan S., 1993. Studies on the ecology of two ponds in Bangladesh Agriculture University Campus, Mymensingh. J. Aquacult. 5(1), 23-27.

Nadra, H. A. M., 2004. Testing some various botanical powders for protection of wheat grain against Trogoderma granarium Everts. J. Biol. Sci. 4(5), 592-597.

Nadra, H. A. M., 2006. Use of Sesbania sesban (L.) Merr. seed extracts for the protection of wheat grain against the granary weevil, Sitophilus granarius (L.) (Coleoptera: Curculionidae). Scient. J. King Faisal Uni. (Basic Appl. Sci.). 7(2), 121-135.

Ngane, A.N., Biyiti L., Bouchet P.H., Nkegfact A., and Zolo P.H.A. (2003). Antifungal activity of Piper guineense of Cameroon. Fitoter. 4(5), 464-468.

Ntonifor, N. N., Oben, O. E., Konje, B. C., 2010. Use of selected plant- derived powders and their combinations to protect stored cowpea grains against damage by Callosobruchus maculatus. J. Agric. Biol. Sci. 5, 13-21.

Oboh, G., Rocha, J.B.T., 2006. Water extractable phytochemicals from Capsicum pubescens (Tree pepper) inhibit lipid peroxidation induced by different pro - oxidant agents in brain. UNESCO and International Atomic Energy Agency. Available at: http://www.ictp.it/pub_off

Olaifa, J.I., Erhun, W.O., Akingbohungbe, A.E.,1987. Insecticidal activity of some Nigerian plants. Insect Sci. Appln. 8(2), 221224.

Omodamiro, O.D., Ekeleme, C. M., 2013. Comparative study of in vitro antioxidant and antimicrobial activities of Piper guineense, 
Curmuma longa, Gongronema latifolium, Allium sativum, Ocimum gratissimum. World J. Med. Medl. Sci. 1(4), 51-69.

Oparaeke, A.M., Bunmi, J.O., 2006. Bioactivity of two powdered spices (Piper guineense schum and thonn and Xylopia aethiopica (Dunal) A. Richards) as homemade insecticides against Callosobruchus subinnotatus (Pic) on stored bambarra groundnut. Agric. Trop. Subtrop. 39, 132-135.

Owolabi, M. S., Oladimeji, M. O., Lajide, L., Singh, G., Marimuthu, P., Isidorov, V. A., 2009. Bioactivity of three plant derived essential oils against the maize weevils Sitophilus zeamais (Motschulsky) and cowpea weevils Callosobruchus maculatus (Fabricius) Elect. J. Environ. Agric. Food Chem. 8, 828-835.

PAN Africa. 2003. Les pesticides au Sénégal $2^{\text {ème }}$ édit. 56p.

Parmar, V.S., Jain, S.C., Bisht, K.S., Jain, R., Taneja, P. et al., 1997. Phytochemistry of the genus Piper. Phytochemistry. 46, 597-673.

Rajapakse, R.H.S., 2006. The potential of plants and plant products in stored insect pest management. J. Agric. Sci. 2, 11-21.

Rehm, S., Espig, G., 1991. The cultivated plants of the tropics and sub-tropics (translated by McNamara, G., Ernsting, C.). Verlay Josef Margraf, Germany, viii + 552 pages. ISBN 38236-1169-0.

Salvador, N., Gómez, G, A., Lavelli, L., Ribera, M.A., 2007. Antimicrobial activity of Iberian macroalgae. Sci. Mar. 71, 101-113.

Shayesteh, N., Ashouri, S., 2010. Effect of four powdered spices as repellents against adults of Rhyzopertha dominica (F.), Sitophilus granarius (L.) and Tribolium castaneum (Herbst) in laboratory conditions. 10th
International Working Conference on Stored Product Protection, (27 June-2 July), Portugal. pp.799-804.

Sighamony, S.I.A., Chandrakala, T. S., Osmani, Z. 1984. Natural products as repellents for Tribolium castaneum Herbst. Int. Pest Contr. 26, 156-157.

Tapondjou, A. L., Adler, C., Fontem, D. A., Bouda, H., Reichmuth, C., 2005. Bioactivities of cymol and essential oils of Cupressus sempervirens and Eucalyptus saligna against Sitophilus zeamais Motschulsky and Tribolium confusum du Val. J. Stored Prod. Res. 41, 91-102.

Tapondjou, L. A., Adler, C., Bouda, H., Fontem, D. A., 2002. Efficacy of powder and essential oil from Chenopodium ambrosioides leaves as post-harvest grain protectants against six-stored product beetles. J. Stored Prod. Res. 38(4), 395402.

Togola, A., Nwilene, F.E., Chougourou, D.C., Agunbiade, T., 2010. Présence, populations et dégâts de l'alucite des céréales Sitotroga cerealella (Olivier) (Lepidoptera, Gelechiidae) sur les stocks de riz au Bénin. Cah. Agric. 19, 205-209.

Udo, I. O., 2005. Evaluation of the potential of some local spices as stored grain protectants against the maize weevil Sitophilus zeamais Mots (Coleoptera: Curculionidae). J. Appl. Sci. Environ. Manag. 9(1), 165-168.

Upadhyay, R. K., Jaiswal, G., 2007. Evaluation of biological activities of $P$. nigrum oil against $T$. cataneum. Bull. Insectol. 60, 57-61.

Wolfson, J. L., Shade, R. E., Mentzer,P. E., Murdock, L. L., 1991. Efficacy of ash for control of Callosobruchus maculatus (F). (Coleoptera: Bruchidae) in stored cowpea. J. Stored Prod. Res. 27, 239-243.

\section{How to cite this article:}

Pegalepo, E., Bokonon-Ganta, A. H., Dossou, J., Sie, M., Ndogho, P. A., 2018. 2018. Review on the use of black pepper (Piper spp.) and red pepper (Capsicum spp.) as grain protectants. Int. J. Curr. Res. Biosci. Plant Biol. 5(10), 14-20. doi: https://doi.org/10.20546/ijcrbp.2018.510.003 